\title{
Seismic Performance Assessment of a Multistoried Building and Retrofitting of RC Columns
}

\author{
Abu Hasan ${ }^{1}$, Md. Golam Kibria ${ }^{2}$, F.M. Mahmud Hasan ${ }^{3}$ \\ ${ }^{1,3}$ (Department of Civil Engineering, European University of Bangladesh, Bangladesh) \\ ${ }_{2}^{2}$ (Department of Civil Engineering, Sonargoan University, Bangladesh)
}

\begin{abstract}
Earthquake is a major concerned natural disaster that causes great damage to the structure. Many multistoried commercial, factory and also residential building in Bangladesh are not designed properly considering seismic loads and also seismic zone effects, thereby large storey displacement and cracks have been observed in the structures. In the present study, a G+10 storied factory building is considered and finite element analysis software ETABS 2015 is used to determine the seismic demand and capacity of each structural element considering seismic zone 1 and zone 3. The building is preliminary designed and analyzed for zone 1 and found safe against seismic loads but vulnerable at zone 3. In the developing countries like Bangladesh, RC jacketing method is popular due to its cost effectiveness comparing with other strengthening methods. Therefore, in this study, a guideline for strengthening of columns only by RC jacketing method is discussed and analyzed. The columns having Demand Capacity Ratio (DCR) ratio more than 1.0 found from analysis are considered to strengthen. Pushover analysis is done to determine the performance of the structure before and after retrofitting and it is found that structure after retrofit have more base shear and displacement capacity, and less storey drift compared to unretrofitted structure.
\end{abstract}

Keywords: Seismic Zone, Retrofitting, Pushover Analysis, Demand Capacity Ratio, Storey Drift

\section{Introduction}

Retrofitting refers to the addition of new materials to enhance the existing structural capacities including the strength, stiffness, stability, and integrity of a building that is found to be deficient or vulnerable. It is required when the compressive strength of the concrete or the percentage and type of reinforcement are not sufficient according to the codes' requirements and also when columns are exposed to an earthquake or an accident such as collisions, fire and explosions. It can effectively raise the performance of a building against earthquake to a desired level, and to even satisfy the requirements of an upgraded design seismic code Gupta et al [1]. The most common types of retrofitting techniques are reinforced concrete (RC) jacketing, steel jacketing and jacketing with high tensile fibre reinforced polymer (FRP) like carbon, glass and aramid fibre etc. This type of strengthening improves the axial and shear strength of columns. RC jacketing of columns consists of the addition of concrete with longitudinal and transverse reinforcement around the existing columns. From different studies [2,3], it is proved that RC jacketing is a very effective strengthening method.

Ranjan and Dhiman [4] studied on the design procedure of Reinforced Concrete (RC), Carbon Fibre Reinforced Polymer (CFRP) and Steel Fibre Reinforced Concrete (SFRC) jacketing of failed columns for an existing building and compared the suitability of these three methods of retrofitting. For their work, a $(\mathrm{G}+3)$ storey building with $3 \mathrm{~m}$ each storey height was modelled and analyzed in STADD.Pro software. RC jacketing to these columns were designed as per IS code 15988:2013. They concluded that, the RC jacketing technique gives significant improvement in moment resisting capacity, shear strength capacity in beam and axial load carrying capacity in column and also FRP Jacketing is costlier as compared to RC and SFRC jacketing but better than RC and SFRC jacketing.

Suresh and Sachin [5] considered an L-shape multistoried building for evaluation and retrofitting work that was designed and constructed only for gravity loads. In their study, RC jacketing was used to increase the capacity of deficient columns having demand to capacity ratio more than 1 and re-analyzed to check the performance of the structure in non-linear analysis or pushover analysis by using finite element software ETABS. It was found that the structure after retrofit have more base shear capacity and displacement capacity, and less storey drift. An experimental investigation on the effectiveness of strengthening half height full size concrete columns by placing concrete jackets was carried out by Vandoros and Dritsos [6]. The same cross sectional dimensions and amount of steel reinforcement were used for the strengthened specimens and a control monolithic specimen. A significant strength and stiffness increase was observed even when the jacket was constructed with no treatment at the interface.

Campione et al [7] analyzed the behaviour in compression of RC columns externally strengthened with concrete jacketing and then developed a cross-section analysis of the jacketed member under axial load and 
bending moment. The analysis showed that the reinforcing technique is effective in improving both the strength and the ductility of RC cross-sections of columns. Spoorthi et al [8] performed a pushover analysis of a tall building with symmetrical plan and elevation of 5,10,15 storey building. The buildings were analyzed by using ETABS 9.7.4 for seismic zone V. Base shear, storey displacements, storey drifts and storey shears obtained from pushover analysis are about twice the storey displacements, storey drifts and storey shears of equivalent static analysis.

In this work, a G+10 storied factory building is considered to investigate the capacity of the building in both linear static analyses and non-linear static analysis (pushover analysis). The building is preliminary modelled and analyzed considering seismic effect for zone 1 by ETABS 2015 and found safe against seismic forces in the linear static analysis. Then the analysis was carried out for zone 3 and the capacity of column with existing reinforcement is then compared with demand posed by the analysis. In ETABS the DCR values for column can be found as PMM ratio and the elements having PMM ratio more than 1.0 are considered to increase the capacity by RC jacketing. A retrofitting model is also prepared with ETABS to analyze and compare the capacity of those deficient columns. Finally, the models are subjected to pushover analysis to compare the performance of the structure before and after retrofitting. This study aims to provide a guideline for $\mathrm{RC}$ retrofitting design and analysis with ETABS and to compare the seismic performance of the building before and after retrofitting.

\subsection{Configuration of the model}

\section{Model descriptions}

A G+10 storied RC moment resisting frame building with plan dimension of $35.0 \mathrm{~m} \times 22.0 \mathrm{~m}$ (7-bay @ $5 \mathrm{~m}$ c/c along X axis and 4-bay @ 5.5m c/c along Y axis) is considered for this study. The plan and 3D view of the model are shown in Fig. 1 and Fig. 2 respectively. Height of each story is $3.0 \mathrm{~m}$ and height below ground level is $2.5 \mathrm{~m}$. All floor slabs, beams and columns are modelled and analyzed as shell element, beam element and column element respectively.

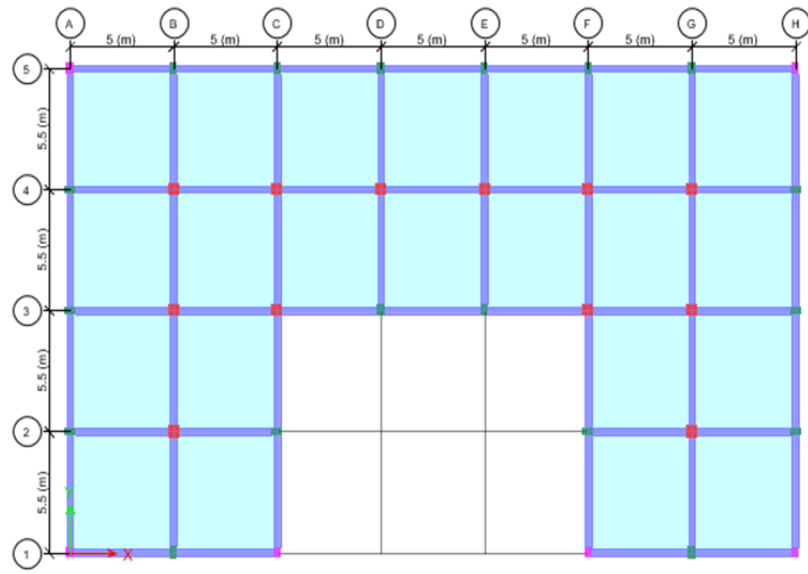

Figure 1: Plan of the RC building model

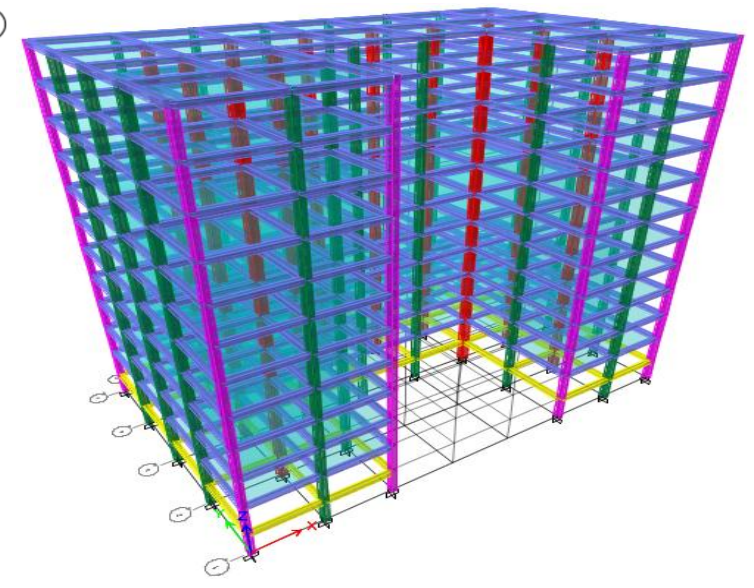

Figure 2: 3D View of the RC building model

Following structural data is used in the model and analysis of the RC building.

Floor Slab

Floor Beam (FB)

Grade Beam (GB)

Column
: $150 \mathrm{~mm}$ thick

: $300 \mathrm{~mm} \times 450 \mathrm{~mm}$

: $300 \mathrm{~mm} \times 500 \mathrm{~mm}$

: Details of column sections are tabulated in Table 1.

Table 1: Details of primary columns

\begin{tabular}{|l|c|c|c|c|}
\hline \multirow{2}{*}{$\begin{array}{c}\text { Column ID } \\
(\& \text { location })\end{array}$} & $\begin{array}{c}\text { Cross section } \\
(\mathrm{mm} \times \mathrm{mm})\end{array}$ & \multicolumn{2}{|c|}{ Vertical reinforcement } & Transvers reinforcement \\
\cline { 3 - 5 } & & Nos. \& size & $\%$ of rebar & Size \& spacing \\
\hline C1(corner) & $350 \times 500$ & $12-\varnothing 20 \mathrm{~mm}$ & 2.15 & $\varnothing 10 \mathrm{~mm} @ 175 \mathrm{~mm} \mathrm{c} / \mathrm{c}$ \\
\hline C2 (edge) & $350 \times 550$ & $16-\varnothing 20 \mathrm{~mm}$ & 2.61 & $\varnothing 10 \mathrm{~mm} @ 175 \mathrm{~mm} \mathrm{c/c}$ \\
\hline C3 (middle) & $550 \times 550$ & $20-\varnothing 20 \mathrm{~mm}$ & 2.08 & $\varnothing 10 \mathrm{~mm} @ 175 \mathrm{~mm} \mathrm{c/c}$ \\
\hline
\end{tabular}

\subsection{Materials properties}

Properties of concrete

Main structural concrete

$\mathrm{RC}$ jacketing concrete

Unit weight of concrete

$$
\begin{aligned}
& =\mathrm{M} 25 \\
& =\mathrm{M} 30 \\
& =23.56 \mathrm{kN} / \mathrm{m}^{3}
\end{aligned}
$$


Modulus of elasticity, Ec

Poisson's ratio

Properties of steel

Yield strength, fy

Modulus of elasticity, Es

$$
\begin{aligned}
& =4700 \sqrt{ } \mathrm{f}^{\prime} \mathrm{c} \\
& =0.2 \\
& =415 \mathrm{MPa} \\
& =199948 \mathrm{MPa}
\end{aligned}
$$

\subsection{Loads on the structure}

Live load

Live load on each floor

Live load on roof

Dead Load

Self weight of the structures

Floor finish load

Interior partition wall load

Peripheral partition wall load

Seismic coefficients for load calculation

Seismic Zone Factor, Z

Site Coefficient, S

$=4.0 \mathrm{kN} / \mathrm{m}^{2}$

$=1.5 \mathrm{kN} / \mathrm{m}^{2}$

$=$ calculated from unit weight

$=1.5 \mathrm{kN} / \mathrm{m}^{2}$

$=1.5 \mathrm{kN} / \mathrm{m}^{2}$

$=4.5 \mathrm{kN} / \mathrm{m}$ (on beam)

$=0.075($ Zone 1$)$

$=0.25$ (Zone 3$)$

$=1.2$

$=1.0$

Importance Factor, I

All superimposed dead load mentioned above is considered for seismic load of the structure. As per BNBC 2006 [9], a minimum of $25 \%$ of the floor live load shall be applicable for storage and warehouse occupancies. However, in this analysis $50 \%$ of the floor live load is considered in seismic weight calculations.

\subsection{Load combinations}

Following load combinations are used from BNBC 2006 to calculate the ultimate load and to check the capacity of the structural elements.
1. 1.4 DL+1.7 LL
2. $1.05 \mathrm{DL}+1.275 \mathrm{LL}+1.4025 \mathrm{EQx}$
6. 1.4 DL+1.4 LL+ 1.4 EQx
3. $1.05 \mathrm{DL}+1.275 \mathrm{LL}-1.4025 \mathrm{EQx}$
7. 1.4 DL+1.4 LL - 1.4 EQx
4. 1.05 DL+1.275 LL+1.4025 EQy
8. 1.4 DL+1.4 LL+ 1.4 EQy
9. 1.4 DL+1.4 LL - 1.4 EQy

5. 1.05 DL+1.275 LL - 1.4025 EQy

Where, $\mathrm{DL}=$ Dead load, $\mathrm{LL}=\mathrm{Live}$ load, $\mathrm{EQx}=$ Earthquake load in $\mathrm{X}$ axis and $\mathrm{EQy}=$ Earthquake load in $\mathrm{Y}$ axis

\section{Analytical method}

As per BNBC 2006 [9] section 2.5.5.1, Equivalent Static Force Method may be used if the height of the regular structure does not exceed 75 metres and also if the structure is regular. The height of the model is 35.5 and the plan is found regular in all respect; therefore, the analysis is carried out by linear static method. Modelling and analysis of the structure is done on ETABS 2015 software. Ultimate Strength Design (USD) method as per ACI 318-11 (for analysis in ETABS 1015) is adopted because the analysis and design formulas in BNBC 2006 are same as ACI 318-11 [10] excepting the strength reduction factors. So, the strength reduction factors are changed in ETABS for analysis which is given in Table 2. Moreover, customized programs e.g., MS Excel is also used for analysis and design checking of some elements.

Table 2: Comparison of strength reduction factor

\begin{tabular}{|l|c|c|}
\hline \multicolumn{1}{|c|}{ Coefficient } & ACI 318-11 & BNBC 2006 \\
\hline Phi (Tension controlled) & 0.9 & 0.9 \\
\hline Phi (Compression controlled tied) & 0.65 & 0.7 \\
\hline Phi (Compression controlled spiral) & 0.75 & 0.75 \\
\hline Phi (Shear and/or torsion) & 0.75 & 0.85 \\
\hline
\end{tabular}

The performance of the building before and after retrofitting is assessed with pushover analysis. Pushover analysis is a simplified, static, non-linear method where a predefined pattern of earthquake loads is applied incrementally to the structure until a collapse mechanism is reached. Although, there are different methods for pushover analysis, basically it has been classified into two ways, force controlled and displacement controlled. In the force controlled method, the structure is subjected to lateral forces and the displacements are calculated. On the other hand, in displacement controlled method, the structure is subjected to a displacement profile and the lateral forces are calculated. However, in this work pushover analysis is carried out considering the displacement controlled method. The use of inelastic analysis procedure is an attempt to understand how structures will behave when subjected to earthquake load. 


\subsection{Torsional irregularity}

\section{Results and discussion}

According to BNBC 2006, torsional irregularity shall be considered to exist when the maximum drift at one end of the structure along an axis is greater than 1.2 times the average of the drift at the two ends of the structure along the same axis. Maximum drift (displacement) at one end of the structure along Y axis is $74.3 \mathrm{~mm}$ and at another end of the structure is $82.7 \mathrm{~mm}$.

1.2 times of average drift $=1.2(74.3+82.7) / 2=94.2 \mathrm{~mm}$

Since, the maximum drift value is lesser than this obtained value, hence the torsional irregularity needs not to be considered and the building is regular.

\subsection{P-Delta effects}

According to BNBC 2006, P-Delta effects need not be considered when the ratio of secondary moment to primary moment remains within 0.10 and also where the storey drift ratio does not exceed $0.02 / \mathrm{R}$.

Drift ratio $=$ Maximum displacement $/$ Building height $=82.7 / 35500=0.0023<0.004$ (i.e. $0.02 / 5$ )

Since, the drift ratio is lesser than 0.004 therefore, P-Delta effects are not taken into account in the analysis.

\subsection{Evaluation and retrofitting of the column}

The columns having DCR or PMM ratio more than 1.0 is envisage as deficient and RC jacketing is considered for strengthening of that columns. It is seen from the analysis result that all the three sizes of the columns are found safe at seismic zone 1 but inadequate up to different stories at zone 3 . The entire column of $\mathrm{C} 1$ at storey 1, C2 up to storey 3 and C3 up to storey 2 are found overstressed at zone 3 . The maximum value of PPM ratio of the three columns up to storey 4 is tabulated in Table 3.

Table 3: PMM ratio of column at zone 1 and zone 3

\begin{tabular}{|l|c|c|c|c|c|c|}
\hline \multirow{2}{*}{ Storey } & \multicolumn{2}{|c|}{ C1-350x500 } & \multicolumn{2}{c|}{ C2-350x550 } & \multicolumn{2}{c|}{ C3-550x550 } \\
\cline { 2 - 7 } & Zone 1 & Zone 3 & Zone 1 & Zone 3 & Zone 1 & Zone 3 \\
\hline Storey 1 & 0.664 & 1.051 & 0.855 & 1.234 & 0.887 & 1.142 \\
\hline Storey 2 & 0.644 & 0.942 & 0.826 & 1.117 & 0.874 & 1.027 \\
\hline Storey 3 & 0.653 & 0.944 & 0.813 & 1.096 & 0.788 & 0.909 \\
\hline Storey 4 & 0.605 & 0.878 & 0.724 & 0.974 & 0.705 & 0.824 \\
\hline
\end{tabular}

The following specifications for design of RC jacketing of columns are used in this study:

i) Strength of the new materials shall be equal or at least 5.0 MPa greater than the existing columns [11].

ii) Minimum thickness of RC jacket should be $100 \mathrm{~mm}[11]$.

iii) Minimum area of steel should be $1 \%$ and also no vertical bar shall be further than $150 \mathrm{~mm}$ clear on each side along the tie [9].

iv) The diameter of the transverse reinforcement should not be less than $10 \mathrm{~mm}$ and should have 135-degree hooks with 10 bar diameter anchorage. Vertical spacing of ties shall not exceed one quarter of the minimum member dimension or $100 \mathrm{~mm}$ up to the length $\ell_{o}$ from each joint face of the column. The length $\ell_{o}$ shall not be less than (a) the depth of the member at the joint face or at the section where flexural yielding is likely to occur, (b) one-sixth of the clear span of the member, (c) $450 \mathrm{~mm}$. Spacing in the remaining height of the member shall not exceed the smaller of 6 times the diameter of the longitudinal bars or $150 \mathrm{~mm}$ [9].

\subsubsection{Design of RC jacket for $\mathrm{C} 1-350 \times 500$}

New size of the column, $b=350+2 \times 100=550 \mathrm{~mm}$,

Area of RC jacket

Minimum area of steel required at jacketed section, A's

$$
\begin{aligned}
& \mathrm{d}=500+2 \times 100=700 \mathrm{~mm} \\
& =\{550+(700-2 \times 100)\} \times 2 \times 100=210000 \mathrm{~mm}^{2} \\
& =0.01 \times 210000 \quad=2100 \mathrm{~mm}^{2}
\end{aligned}
$$

Assuming 16mm $\varnothing$ bars, number of bars required, $\mathrm{N} \quad=2100 / 201 \quad=10.44$ bars, say 12 bars

No. of bars along short and long direction of the section, $n=4$

Clear spacing of vertical bars $\quad=\frac{\text { b or } d-2 \times C c-2 \times D t-n \times D v}{n-1}$

Where,

$\mathrm{b}=$ Dimension of the jacketed column along $\mathrm{X}$ axis, $\mathrm{d}=$ Dimension of the jacketed column along $\mathrm{Y}$ axis

$\mathrm{Cc}=$ Clear cover, Dv =Diameter of the vertical bar, $\mathrm{Dt}=$ Diameter of the tie bar

$\mathrm{n}=$ Number of bars along $\mathrm{X}$ or $\mathrm{Y}$ axis

Clear spacing along $\mathrm{X}$ axis

$$
\begin{aligned}
& =\frac{550-2 \times 40-2 \times 10-4 \times 16}{4-1}=128.7 \mathrm{~mm}<150 \mathrm{~mm} \text { (satisfied) } \\
& =\frac{700-2 \times 40-2 \times 10-4 \times 16}{4-1}=178.7 \mathrm{~mm}>150 \mathrm{~mm} \text { (not satisfied) }
\end{aligned}
$$

Clear spacing along $\mathrm{Y}$ axis 
Hence, number of bars need to increse along the long direction, say 5

Clear spacing along long direction $\quad=\frac{700-2 \times 40-2 \times 10-5 \times 16}{5-1}=130.0 \mathrm{~mm}<150 \mathrm{~mm}$ (satisfied)

So, $14-16 \mathrm{~mm} \varnothing$ bars need to be provided.

\subsubsection{Design of $\mathrm{RC}$ jacket for $\mathrm{C2}-350 \times 550$}

New size of the column, $b=350+2 \times 100=550 \mathrm{~mm}$,

Area of RC jacket

Minimum area of steel required at jacketed section, A's

Assuming $16 \mathrm{~mm} \varnothing$ bars, number of bars required, $\mathrm{N}$

No. of bars along short and long direction of the section,

$$
\begin{aligned}
& \mathrm{d}=550+2 \times 100=750 \mathrm{~mm} \\
& =\{550+(750-2 \times 100)\} \times 2 \times 100=220000 \mathrm{~mm}^{2} \\
& =0.01 \times 210000 \quad=2200 \mathrm{~mm}^{2} \\
& =2200 / 201 \quad=10.94 \text { bars, say } 12 \text { bars }
\end{aligned}
$$

$=4$

Clear spacing along $\mathrm{X}$ axis

$$
\begin{array}{ll}
=\frac{550-2 \times 40-2 \times 10-4 \times 16}{4-1} & =128.7 \mathrm{~mm}<150 \mathrm{~mm} \text { (satisfied) } \\
=\frac{750-2 \times 40-2 \times 10-4 \times 16}{4-1} & =195.3 \mathrm{~mm}>150 \mathrm{~mm} \text { (not satisfied) }
\end{array}
$$

Clear spacing along $\mathrm{Y}$ axis

Hence, number of bars need to increse along the long direction, say 5

Clear spacing along long direction $\quad=\frac{750-2 \times 40-2 \times 10-5 \times 16}{5-1}=142.5 \mathrm{~mm}<150 \mathrm{~mm}$ (satisfied)

So, $14-16 \mathrm{~mm} \varnothing$ bars need to be provided.

\subsubsection{Design of $\mathrm{RC}$ jacket for $\mathrm{C} 3-550 \times 550$}

New size of the column, $b=550+2 \times 100=750 \mathrm{~mm}$,

Area of RC jacket

Minimum area of steel required at jacketed section, A's

Assuming $16 \mathrm{~mm} \varnothing$ bars, number of bars required, $\mathrm{N}$

$$
\begin{aligned}
& \mathrm{d}=550+2 \times 100=750 \mathrm{~mm} \\
& =\{750+(750-2 \times 100)\} \times 2 \times 100=260000 \mathrm{~mm}^{2} \\
& =0.01 \times 210000 \quad=2600 \mathrm{~mm}^{2} \\
& =2600 / 201 \quad=12.93 \text { bars, say } 14 \text { bars } \\
& \text { ars along both axis, } \mathrm{n} \quad 5 \quad
\end{aligned}
$$

Clear spacing along $\mathrm{X}$ axis

$$
\begin{aligned}
& =\frac{750-2 \times 40-2 \times 10-5 \times 16}{5-1}=142.5 \mathrm{~mm}<150 \mathrm{~mm} \text { (satisfied) } \\
& =\frac{750-2 \times 40-2 \times 10-5 \times 16}{5-1}=142.5 \mathrm{~mm}<150 \mathrm{~mm} \text { (satisfied) }
\end{aligned}
$$

Clear spacing along $\mathrm{Y}$ axis

So, $16-16 \mathrm{~mm} \varnothing$ bars need to be provided.

The retrofitted sections of the columns are shown in Fig. 3.

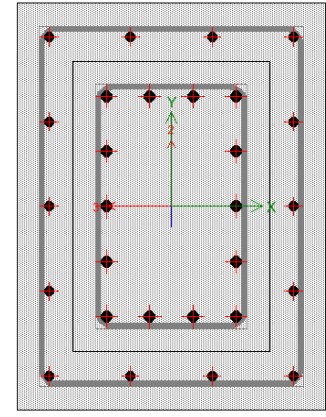

(a) $\mathrm{RC} 1-550 \times 700$

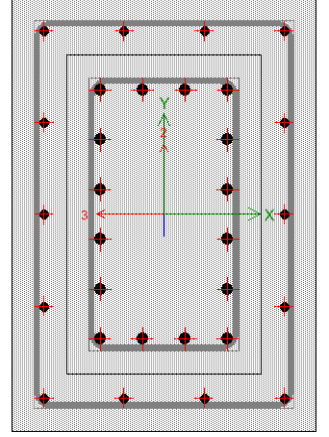

(b) $\mathrm{RC} 2-550 \times 750$

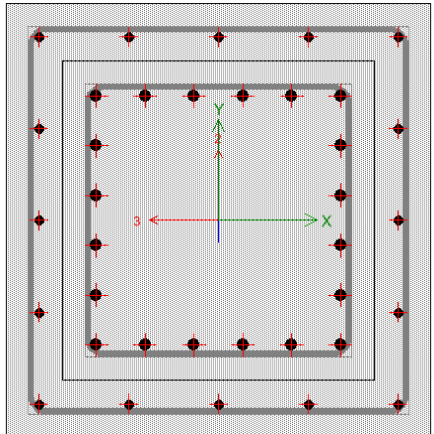

(c) RC3-750x750

Figure 3: Reinforcement detailing of the retrofitted column

After analysis of retrofitted structure it is observed that the capacity of all columns have been increased significantly. The PMM value of the retrofitted columns is given in Table 4.

Table 4: PMM ratio of column after retrofitting

\begin{tabular}{|c|c|c|c|}
\hline Storey & $\mathrm{RC} 1-550 \times 700$ & $\mathrm{RC} 2-550 \times 750$ & $\mathrm{RC} 3-750 \times 750$ \\
\hline Storey 1 & 0.617 & 0.659 & 0.627 \\
\hline Storey 2 & 0.806 & 0.561 & 0.569 \\
\hline Storey 3 & 0.853 & 0.567 & 0.828 \\
\hline Storey 4 & 0.855 & 0.955 & 0.868 \\
\hline
\end{tabular}




\subsection{Story drift}

Storey drift is the displacement of one level relative to the level above or below due to the design lateral forces. Maximum tolerable story drift, $\Delta$ shall be determined from the following relation according to BNBC 2006 section 1.5.6, part 6.

$$
\begin{array}{ll}
\Delta \leq 0.04 \mathrm{~h} / \mathrm{R} \leq 0.005 \mathrm{~h} & \text { for } \mathrm{T}<0.70 \text { second } \\
\Delta \leq 0.03 \mathrm{~h} / \mathrm{R} \leq 0.004 \mathrm{~h} & \text { for } \mathrm{T} \geq 0.70 \text { second }
\end{array}
$$

Where,

$\mathrm{h}=$ Height of the storey

$\mathrm{R}=$ Response modification coefficient

$\mathrm{T}=$ Fundamental period of vibrations can be calculated by $\mathrm{T}=\mathrm{Ct}\left(\mathrm{h}_{\mathrm{n}}\right)^{3 / 4}$

$\mathrm{C}_{\mathrm{t}}=0.073$ for reinforced concrete moment resisting frame

$\mathrm{h}_{\mathrm{n}}=$ Height in meters above the base to level $\mathrm{n}$

Now, $\mathrm{T}=\mathrm{C}_{\mathrm{t}}\left(\mathrm{h}_{\mathrm{n}}\right)^{3 / 4}=0.073 \times(35.5)^{3 / 4}=1.06$ second $>0.7$ second

From equations (3) given above, maximum storey drift limit is found as $11.4 \mathrm{~mm}$ and from the analysis it is observed that the maximum storey drift is $9.0 \mathrm{~mm}$ which is lies within the tolerable limit. In addition to this, a significant reduction of storey drift is noticed from Fig. 4 and Fig. 5 after retrofitting of the deficient columns compared to unretrofitted column.

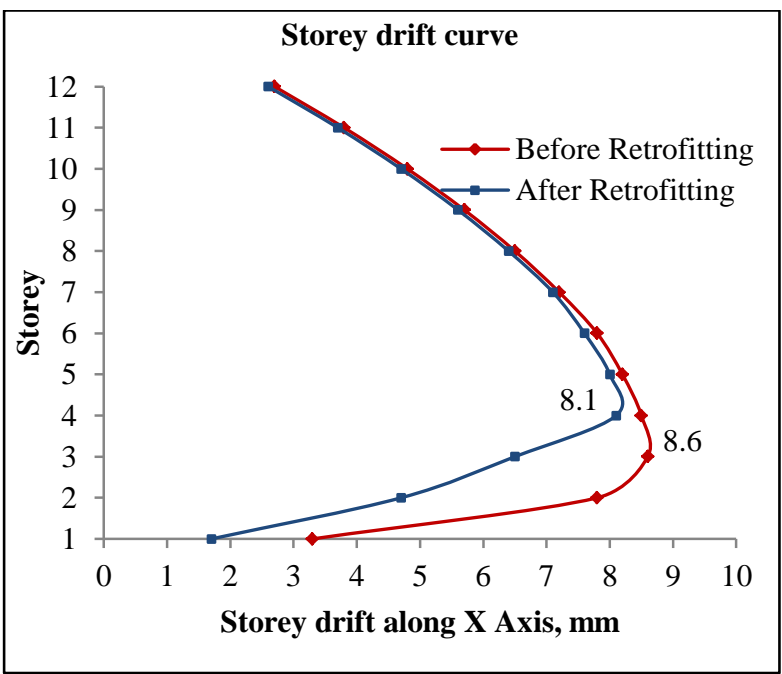

Figure 4: Comparison of storey drifts along $\mathrm{X}$ axis

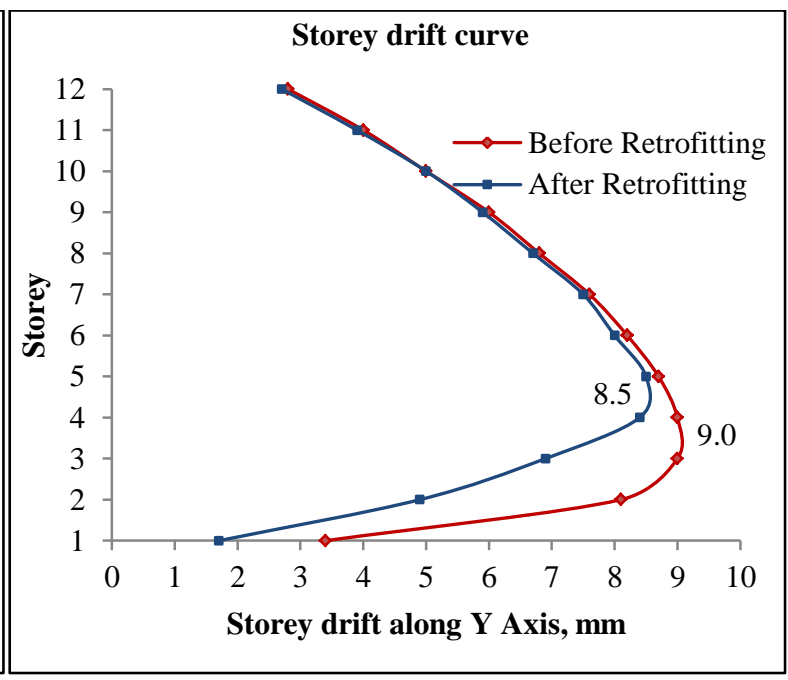

Figure 5: Comparison of storey drifts along $\mathrm{Y}$ axis

\subsection{Displacement}

Maximum displacement of the structure is found along $\mathrm{Y}$ direction in both before and after retrofitting model. It is observed from the Fig. 6 and Fig. 7 that the displacement after retrofitting is reduced by $8.2 \mathrm{~mm}$ and $9.7 \mathrm{~mm}$ in comparison with primary unretrofitted model in $\mathrm{X}$ and $\mathrm{Y}$ direction respectively.

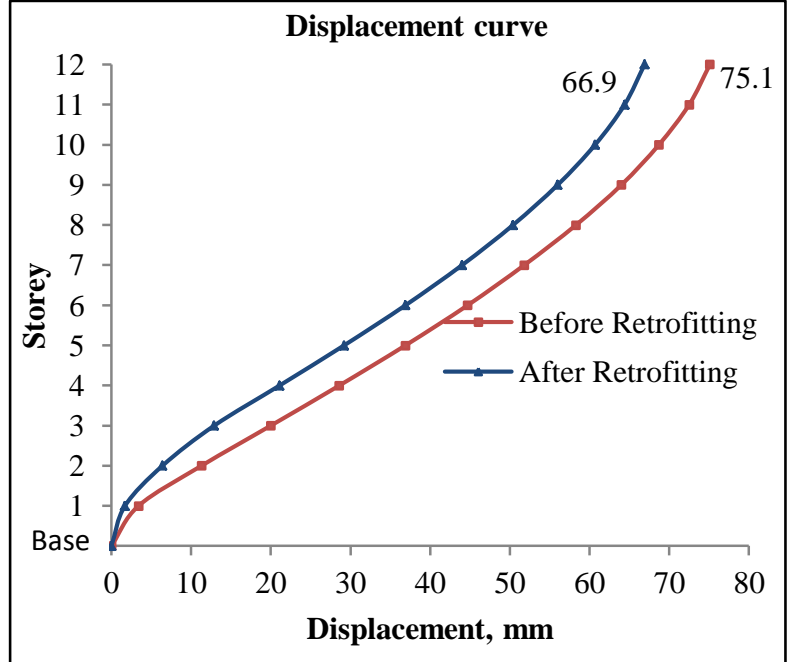

Figure 6: Comparison of displacement along $\mathrm{X}$ axis

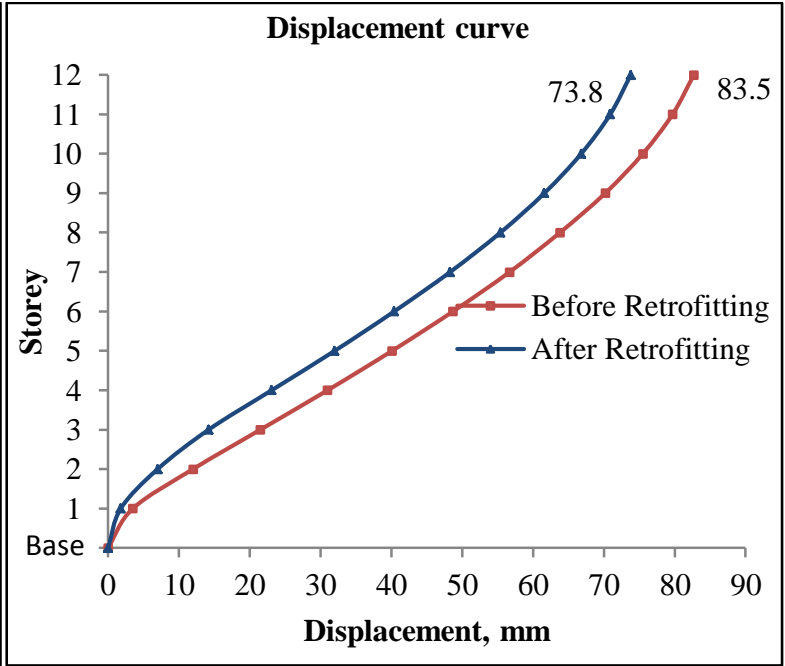

Figure 7: Comparison of displacement along Y axis 


\subsection{Base shear and displacement capacity}

It is observed form the analysis that retrofitting of the columns increases the base shear capacity and also reduces the displacement of the structure. A plot of total base shear versus top displacement of the structure obtained by pushover analysis for both axes is shown in Fig. 8 and Fig. 9 that would indicate any premature failure or weakness. The analysis is carried out up to before collapse prevention level, thus it enables determination of collapse load and ductility capacity, and comparison of the performance of both the retrofitted and unretrofitted column model.

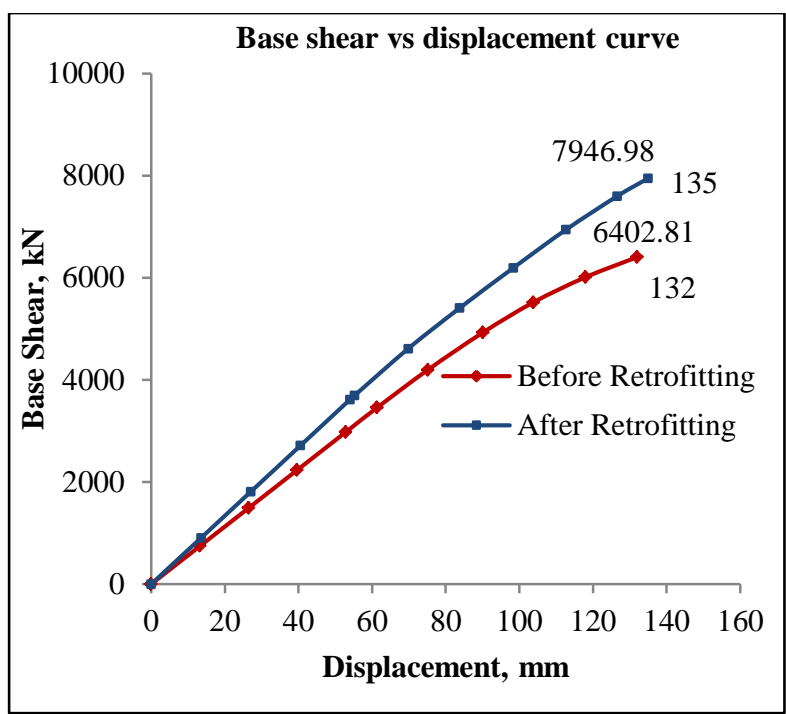

Figure 8: Base shear vs displacement along $\mathrm{X}$ axis

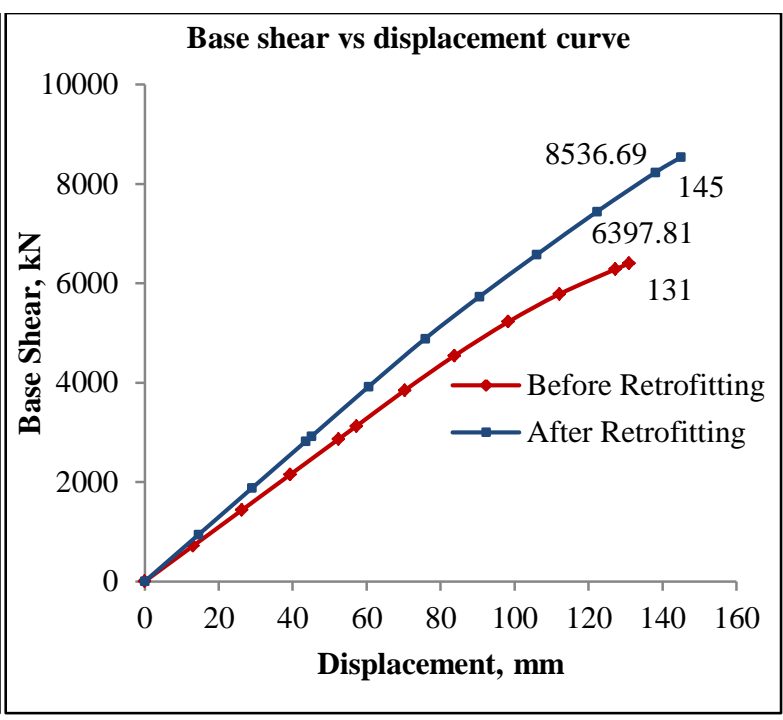

Figure 9: Base shear vs displacement along $\mathrm{Y}$ axis

Although the displacement capacity has not increased significantly except $14 \mathrm{~mm}$ increase in $\mathrm{Y}$ direction but it is found that the base shear capacity rose by $24.13 \%$ in $\mathrm{X}$ direction and $33.43 \%$ in Y direction after retrofitting of the overstressed columns.

\section{Conclusions}

The following conclusions are drawn from this study:

1. Building designed for seismic zone 1 can be inadequate and vulnerable at zone 3 .

2. RC jacketing method significantly increases the DCR of the structure and reduces the storey drift.

3. Base shear and displacement capacity of the structure can be increased and also maximum displacement to prevent collapse of the existing building due to seismic loads can be minimized by RC jacketing.

\section{References}

[1] N. Gupta, P. Dhiman, and A. Dhiman, Design and Detailing of RC Jacketing for Concrete Columns, IOSR Journal of Mechanical and Civil Engineering (IOSR-JMCE), 2015, 54-58.

[2] E.N.B.S. Júlio, and F.A.B. Branco, V.D. Silva, Reinforced concrete jacketing -interface influence on monotonic loading response, ACI Structural Journal, 102(2), 2005, 252-257.

[3] E.S. Julio, F. Branco and V. D. Silva, Structural rehabilitation of columns with reinforced concrete jacketing, Progress in Structural Engineering and Materials, 5, 2003, 29-37. DOI: 10.1002/pse. 140

[4] P. Ranjan, and P. Dhiman, Retrofitting of columns of an existing building by RC, FRP and SFRC jacketing techniques, IOSR Journal of Mechanical and Civil Engineering (IOSR-JMCE), Special Issue - AETM'16, 2016, 40-46.

[5] G.S. Suresh, and V. Sachin, Seismic Performance evaluation and retrofitting of RC members and joints, International Journal of Current Engineering and Scientific Research (IJCESR), 2(2), 2015, 98-111.

[6] K.G. Vandoros, and S.E. Dritsos, Concrete jacket construction detail effectiveness when strengthening RC columns, Construction and Building Materials, 22(3), 2006, 264-276.

[7] G. Campione, M. Fossetti, C. Giacchino, and G. Minafo, RC columns externally strengthened with RC jackets, Materials and Structures, 47(10), 1715-1728. DOI: 10.1617/s11527-013-0146-x

[8] S.K. Spoorthi, and G. Jagadishkori, Effect of soft storey on tall buildings at various storeys by pushover analysis, International journal of Engineering Research, 3, 2014, 91-98.

[9] BNBC 2006, Bangladesh National Building Code, Bangladesh, 2006. 
[10] ACI 318-11, Building Code Requirements for Structural Concrete with Commentary, American Concrete Institute, 2011.

[11] IS 15988:2013, 2013, Seismic Evaluation and Strengthening of Existing Reinforced Concrete Buildings -Guidelines, Bureau of Indian Standards, New Delhi, 2013. 